\title{
LYAR, a novel nucleolar protein with zinc finger DNA-binding motifs, is involved in cell growth regulation
}

\author{
Lishan Su, R. Jane Hershberger, ${ }^{1}$ and Irving $L$. Weissman \\ Departments of Developmental Biology and Pathology, Stanford University, Stanford, California 94305 USA
}

\begin{abstract}
A cDNA encoding a novel zinc finger protein has been isolated from a mouse T-cell leukemia line on the basis of its expression of a Ly-1 epitope in a $\lambda$ gt11 library. The putative gene was mapped on mouse chromosome 1, closely linked to Idh-1, but not linked to the Ly-1 (CD5) gene. The cDNA is therefore named Ly-1 antibody reactive clone (LYAR). The putative polypeptide encoded by the cDNA consists of 388 amino acids with a zinc finger motif and three copies of nuclear localization signals. Antibodies raised against a LYAR fusion protein reacted with a protein of $45 \mathrm{kD}$ on Western blots and by immunoprecipitation. Immunolocalization indicated that LYAR was present predominantly in the nucleoli. The LYAR mRNA was not detected in brain, thymus, bone marrow, liver, heart, and muscle. Low levels of LYAR mRNA were detected in kidney and spleen. However, the LYAR gene was expressed at very high levels in immature spermatocytes in testis. The LYAR mRNA is present at high levels in early embryos and preferentially in fetal liver and fetal thymus. A number of B- and T-cell leukemic lines expressed LYAR at high levels, although it was not detectable in bone marrow and thymus. During radiation-induced T-cell leukemogenesis, high levels of LYAR were expressed in preleukemic thymocytes and in acute $T$ leukemia cells. Fibroblast cells overexpressing the LYAR cDNA from a retrovirus vector, though not phenotypically transformed in vitro, had increased ability to form tumors in nu/nu mice. Therefore, LYAR may function as a novel nucleolar oncoprotein to regulate cell growth.
\end{abstract}

[Key Words: Zinc finger protein; nucleolus; radiation-induced thymic leukemogenesis]

Received December 14, 1992; revised version accepted March 3, 1993.

Oncogenic transformation of cells leads to a number of changes in cellular metabolism, physiology, and morphology. One of the major changes is the pleomorphism and hyperactivity of the nucleolus (Yeoman et al. 1976; Busch et al. 1979, 1986). Nucleolar proteins have been identified that are specifically expressed in actively dividing cells and tumor cells (Reddy et al. 1989). The functions of these proteins are not clear, and it has been speculated that they may be involved in cell growth regulation (Tan 1982; Mathews et al. 1983) and in transcriptional control (Dynan and Tjian 1983).

The precise molecular pathways and secondary changes leading to malignant transformation for most cell types are not clear. A number of cases have been reported in which altered expression or activity of some proteins with putative DNA-binding motifs are found in some tumors or leukemias. For example, chromosomal translocations involving lyl-1 [a protein with a putative DNA-binding motif [Mellentin et al. 1989)] and the fusion proteins between RAR $\alpha$ and PML [a zinc fingerencoding gene (de The et al. 1991; Goddard et al. 1991)] are detected in some leukemic cell lines. In two recent

${ }^{1}$ Present address: Department of Biological Sciences, Stanford University, Stanford, California 94305. reports, a zinc finger protein has been identified which, when overexpressed, appears to cooperate with the myc oncogene to induce B-cell leukemias in transgenic mice (Haupt et al. 1991; van Lohuizen et al. 1991).

The zinc finger domain is a sequence-specific DNAbinding motif in a family of proteins that was first identified in the Xenopus laevis transcription factor IIIA (Miller et al. 1985). Substantial evidence has established these proteins as a class of trans-acting molecules with regulatory roles in cellular growth and differentiation. Here, we report a cDNA isolated from a T-cell leukemia line which encodes a putative nuclear protein with zinc finger motifs. We present evidence that the protein is localized in the nucleolus of cells. Expression of the gene is induced during radiation-induced thymic leukemogenesis in mice. Over-expression of the cDNA in NIH$3 \mathrm{~T} 3$ cells increases their tumorigenic potential in $\mathrm{nu} / \mathrm{nu}$ mice.

\section{Results}

Isolation of a cDNA encoding a zinc finger protein from a mouse T-cell leukemia line

In an attempt to clone the T-cell surface marker Ly-1 \{CD5) several years ago (Hershberger 1989), a $\lambda$ gt11 li- 
brary from the leukemic T cell EL4 was screened with the anti-Ly-1 monoclonal antibody 53.7 (Ledbetter and Herzenberg 1979|. The Ly-1 antibody reactive clone (LYAR) was characterized and sequenced. It was ruled out as encoding Ly-1 by chromosomal mapping (see below). Comparison of LYAR to the Ly-1 sequences, subsequently elucidated by others (Huang et al. 1987), showed that they encoded polypeptides with no significant similarity.

The LYAR clone encodes a 1164-bp open reading frame consisting of 388 amino acids (Fig. 1A). A sequence similarity search of the gene bank data bases revealed no significant similarity to any known genes either at the DNA or at the amino acid levels (data not shown). Further inspection of the encoded polypeptide revealed that two putative zinc finger domains are present in the first 60 amino acids (Fig. 1A, underlined). Both of the zinc finger motifs are similar to the standard zinc finger consensus sequence (Berg 1986), although the space between the last two zinc-binding residues (Cys or His) is two instead of three amino acids.

Recently, a new family of zinc finger proteins has been identified whose spacing between the last two zinc-binding residues consists of two instead of three amino acids (Fig. 1B; Goddard et al. 1991; Haupt et al. 1991; van Lohuizen et al. 1991). These proteins all have eight zincbinding residues (Cys or His) in a cluster $\left(\mathrm{C}_{4} \mathrm{HC}_{3}\right)$ at their amino termini. The putative zinc finger domains at the amino terminus of LYAR fit the consensus of this new class of zinc finger motifs (Fig. 1B), although the LYAR domain has the His residue in a different position $\left(\mathrm{C}_{6} \mathrm{HC}\right)$. Overall, this Cys/His motif seems to characterize proteins that interact with DNA. Most of the proteins are implicated in cell proliferation and tumorigenesis, and other regulatory functions.

Three copies of nuclear localization signals (NLS) are also detected in the protein (Fig. 1A,C). One is almost identical to the first NLS identified in the SV40 T antigen (Kalderon et al. 1984a,b). The other two are bipartite nuclear localization signals (BNLS) similar to the ones identified in nucleoplasmin and thyroid $\beta$-receptor (Robbins et al. 1991). Thus, the LYAR cDNA appears to encode a nuclear protein with a putative DNA-binding motif.

A sequence search for conserved motifs also revealed that LYAR has a potential site for tyrosine phosphorylation immediately following the second zinc finger (double underlined in Fig. 1A). A potential Ser residue for cAMP-dependent protein kinase is also detected at the carboxyl terminus (Fig. 1A, carboxyl terminus underline). In addition, a stretch of amino acids is found to be mostly charged residues (32 of 47$)$ with a positive net charge (11 negative, 21 positive residues; Fig. 1A, wavy underlinel.

\section{Chromosomal location of the LYAR gene}

The chromosomal location of the LYAR gene in mice was established using the BXD recombinant inbred strains (Bailey 1971). A restriction fragment length poly- morphism (RFLP) for LYAR between the BXD parental strains $\mathrm{C} 57 \mathrm{Bl} / 6$ and DBA was identified, and this was used to determine the strain distribution pattern of the LYAR locus in 21 BXD mice (Table 1). The strain distribution pattern for LYAR exactly matched that of isocitrate dehydrogenase-1 $\{I d h-1\}$ on chromosome 1, implying that these loci are tightly linked $(\mathrm{P}>0.99)$. Adjacent loci on chromosome 1 also showed significant linkage, which diminished with increasing distance from Idh-1. The proximal chromosome 1 markers gave the best match to LYAR of 144 loci on 16 chromosomes (Taylor 1989).

\section{LYAR, a 45-kD protein, is localized predominantly in the nucleolus}

Antibodies were raised against a LYAR fusion protein produced in bacteria. The purified antibodies specifically recognized a protein of $45 \mathrm{kD}$ from EL4 cells, which was not detected in a bone marrow-derived stromal cell line (AC6) on Western blot (Fig. 2A,B).

By immunoprecipitation of labeled cell extracts, it was shown that the antibody reacted with a protein of $\sim 45$ $\mathrm{kD}$, which was not detected in AC6 cells, and the preimmune antiserum did not react with this protein (Fig. $2 \mathrm{Cl}$. The mobility of the protein on SDS-PAGE did not change under reducing or nonreducing conditions (data not shown|.

Indirect immunofluorescence staining was performed to localize the LYAR protein in mouse cell lines and in COS-7 cells transfected with the LYAR cDNA. The LYAR protein was localized predominantly in some subcompartments of the nuclei of $\mathrm{T}$ or B leukemia cells (data not shown). Using mouse embryonic fibroblast (EF) cells (Fig. 3A), it was shown clearly that the LYAR protein was localized in the nuceoli of the nucleus, which was visualized by staining DNA with Hoechst 33342 .

In addition, COS-7 cells transiently transfected with the LYAR cDNA also showed predominantly nucleolar staining (Fig. 3B). COS-7 cells transfected with the vector plasmid DNA did not give any detectable staining (data not shown). This indicates that the antibody was specific to the protein encoded by the LYAR cDNA. A few of the LYAR-expressing cells, however, seemed to express LYAR at higher levels, and LYAR was localized both in the nucleolus and in the nucleoplasm. Interestingly, the nucleoli of these cells appeared to be more organized along the nuclear membrane (see arrows in Fig. 3B), perhaps as a result of overexpression of LYAR in these cells.

In actively dividing mouse EF cells, the LYAR protein is present mostly in the nucleolus. However, in some cells undergoing mitosis with condensed chromosomal DNA, LYAR protein is localized throughout the cells. The LYAR protein appears to be excluded from the condensed chromosomal DNA (Fig. $3 \mathrm{C}, \mathrm{c}$ ). The rhodamine immunofluorescence signal (red) of LYAR appears to be excluded from nuclear compartments where high levels of DNA (blue or white) are detected (Fig. 3C,c). This indicates that LYAR is probably not an integral part of the chromosomes. 


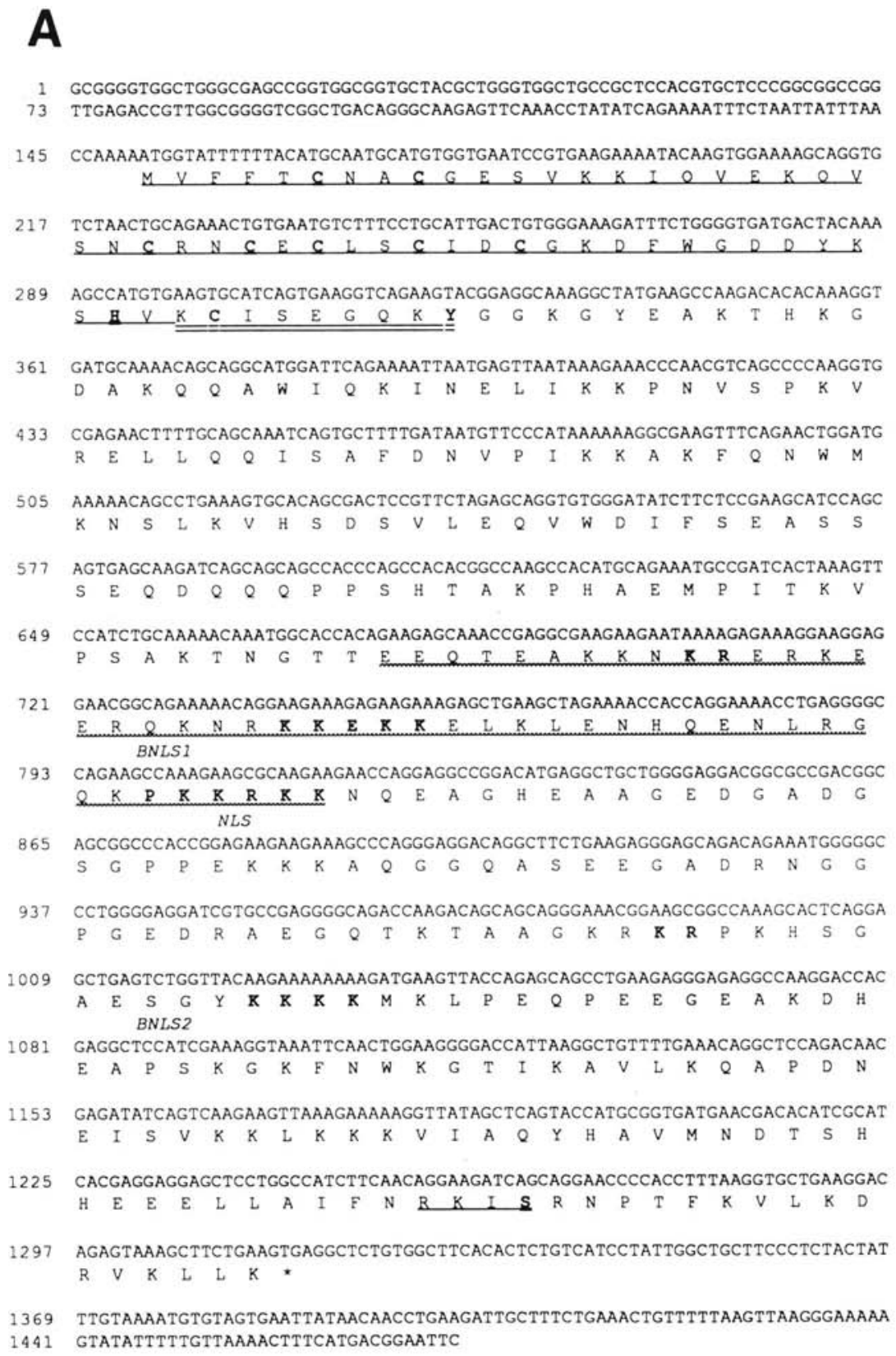

1297 AGAGTAAAGCTTCTGAAGTGAGGCTCTGTGGCTTCACACTCTGTCATCCTATTGGCTGCTTCCCTCTACTAT R V K L L K *

1369 TTGTAAAATGTGTAGTGAATTATAACAACCTGAAGATTGCTTTCTGAAACTGTTTTTAAGTTAAGGGAAAAA 1441 GTATATTTTTGTTAAAACTTTCATGACGGAATTC

B

$\begin{array}{lllrl}\text { PML } & \text { QFLRCQQCQ } & \text { AEAKCP } & \text { KLLPCLHTLCSGCLEAS } & \text { GMQCPICQAPWPL } \\ \text { RPt-1 } & \text { EEVTCPICL } & \text { ELLKEPV } & \text { SADCNHSFCRACITLN YESNRNTDGKGNCPVCRVPYPF } \\ \text { IE110 } & \text { EGDVCAVCT } & \text { DEIAPHL } & \text { RCDTFPCMHRFCIPCMKTW MQL } & \text { RNTCPLCNAKLVY } \\ \text { MEL-18 } & \text { PHLMCALCG } & \text { GYFIDAT } & \text { TIVECLHSFCKTCIVRY LET } & \text { NKYCPMCDVQVHK } \\ \text { bmi-1 } & \text { PHLMCVLCG } & \text { GYFIDAT } & \text { TIIECLHSFCKTCIVRY LET } & \text { SKYCPICDVQVHK } \\ \text { IfP } & \text { QETTCPVCL } & \text { QYFAEPM } & \text { MLDCGHNICCACLARC WGT } & \text { AETNVSCPQCRETFPQ } \\ \text { RAG-1 } & \text { KSISCQICE } & \text { HILADPV } & \text { ETNCKHVFCRVCILRC LKV } & \text { MGSYCPSCRYPCFP } \\ \text { RAD-18 } & \text { TLLRCHICK } & \text { DELKVPV } & \text { LTPCGHTCSLCIRTH LNN } & \text { QPNCPLCLFEFRE } \\ \text { VZV61 } & \text { SDNTCTICM } & \text { STVSDLG } & \text { KTMPCLHDFCFVCIRAW TST } & \text { SVQCPLCRCPVQS } \\ \text { T-LR } & \text { TYGMCAVCR } & \text { EPWAEGA } & \text { VELLPCRHVFCTACVVQR WR } & \text { CPSCQRRIGG } \\ \text { SS-A/RO } & \text { EEVTCPICL } & \text { DPFVEPV } & \text { SIECGHSFCECISQV GKG } & \text { GGSVCAVCRQRFLL } \\ \text { RING1 } & \text { SELMCPICL } & \text { DMLKNTM } & \text { TTKECLHRFCSDCIVTA LRS } & \text { GNKECPTCRKKLVS } \\ \text { CG30 } & \text { VKLQCNICFSVAEIKNYFLQPIDRLTIIPVLELDTCKHQLCSMCIRKI RKR } & \text { KKVPCPLCRVESLH } \\ \text { PE-38 } & \text { FKFECSVCL } & \text { ETYSQQSN DTCPFLIPTTCDHGFCFKCVINLQSNAMNIPHSTVCCPLCNTQVK }\end{array}$

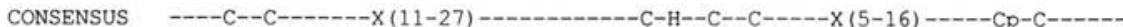

Lyar VFFTCNACG ESVKKIQ VEKQVSNCRNCECLSCIDCGKDE WGD DYKSHVKCISEGQK
SV40 T:
PKKKRK
Lyar (NLS):
PKKRKK (217-222)
Thyroid $\beta$ :
$\mathrm{KRX}_{10} \operatorname{ReKRR}$
Lyar (BNLS1): $\quad$ KRX $_{10}$ KKeKK (185-201)
Nucleoplasmin: $\quad \mathrm{KRX}_{10} \mathrm{KKKK}$
Lyar (BNLS2): $\quad$ KRX 10 KKKK (270-284)

Figure 1. Molecular structure of the LYAR gene. $|A|$ Nucleotide and deduced amino acid sequences of the LYAR cDNA. The zinc finger region is underlined. The double underline indicates a potential Tyr phosphorylation site. The region underscored by a wavy line consists of 47 residues with 32 charged ones ( 11 negative, 21 positive). The three putative NLS are marked with bold letters [(BNLS) bipartite nuclear localization signal; (NLS) SV40 T-type nuclear localization signal)]. A putative phosphorylation site for cAMP-dependent kinase is marked at the carboxyl terminus. $(B)$ The zinc finger motifs of LYAR and a new family of proteins. The residues conserved in all proteins are boxed and defined as the consensus, except Pro $(\mathrm{P})$, which is not conserved in all the proteins. $(\mathrm{X})$ Any amino acid. Residues conserved in LYAR are in bold letters. Sequences not cited in the text are the baculovirus early proteins CG30 (Thiem and Miller 1989) and PE-38 (Krappa and Knebel-Morsdorf 1991), a trypanosome protein with a leucine repeat motif, T-LR (Smiley et al. 1990), and the SS-A/Ro protein (Chan et al. 1991), which is part of a nuclear ribonucleoprotein particle. $|C|$ The putative NLS in the LYAR protein. As marked in Fig. 1A, NLS is aligned with that of the SV40 T. BNLS1 and BNLS2 are aligned with the NLS of thyroid $\beta$-receptor and nucleoplasmin, respectively. $(\mathrm{X})$ Any amino acid. 
Su et al.

Table 1. LYAR pattern distribution in BXD and linkage analysis

\begin{tabular}{|c|c|c|c|c|c|c|c|c|c|c|c|c|c|c|c|c|c|c|c|c|c|}
\hline $\mathrm{BXD}$ & 1 & 5 & 6 & 8 & 9 & 11 & 12 & 14 & 15 & 16 & 18 & 19 & 21 & 22 & 24 & 25 & 27 & 28 & 29 & 30 & 31 \\
\hline LYAR & B & B & $\mathrm{D}$ & $\mathrm{D}$ & B & B & B & B & $\mathrm{D}$ & $\mathrm{D}$ & B & $\mathrm{D}$ & B & B & B & $\mathrm{D}$ & $\mathrm{D}$ & $\mathrm{D}$ & $\mathrm{D}$ & $\mathrm{D}$ & $\mathrm{B}$ \\
\hline \multicolumn{4}{|c|}{ Chromosome 1 locus } & \multicolumn{6}{|c|}{ Distance to $I d h-1(\mathrm{~cm})$} & \multicolumn{6}{|c|}{ Number of differences } & \multicolumn{6}{|c|}{ Probability of linkage } \\
\hline \multicolumn{4}{|l|}{$\overline{A O X-1}$} & \multicolumn{6}{|c|}{$6.43 \pm 1.55$} & \multicolumn{6}{|c|}{$1 / 21$} & \multicolumn{6}{|c|}{$>0.99$} \\
\hline Idh-1 & & & & \multicolumn{6}{|c|}{0} & \multicolumn{6}{|c|}{$0 / 21$} & \multicolumn{6}{|c|}{$>0.99$} \\
\hline Lsh & & & & \multicolumn{6}{|c|}{$11.46 \pm 3.59$} & \multicolumn{6}{|c|}{$6 / 21$} & \multicolumn{6}{|c|}{$\geqslant 0.95$} \\
\hline Pep-3 & & & & \multicolumn{6}{|c|}{$23.31 \pm 1.81$} & \multicolumn{6}{|c|}{$7 / 21$} & \multicolumn{6}{|c|}{$<0.90$} \\
\hline Mls & & & & \multicolumn{6}{|c|}{$31.92 \pm 6.01$} & \multicolumn{6}{|c|}{$9 / 21$} & \multicolumn{6}{|c|}{$<0.90$} \\
\hline
\end{tabular}

Strain distribution pattern of the LYAR RFLP among the BXD recombinant inbred strains C57Bl/6 (B) and DBA (D). The summary of the strain distribution comparisons to loci on chromosome 1, listed in proximal to distal order, is based on data given in Taylor (1989). The genetic distances to Idh-1 are from published results (Davidson et al. 1989), using the combined male and female recombination data. Probability of linkage was calculated by the $\chi^{2}$ distribution.

The LYAR mRNA is detected in a number of T and$B$ leukemia cells but not in most adult mouse tissues

To investigate the expression pattern of LYAR in T- and B-cell leukemias, we first examined its expression in a number of cell lines by Northern blot analyses (Fig. 4A). High levels of LYAR mRNA were detected in all leukemic T (BW, EL4, and VL3.1) and leukemic B (L1-2, 200-2 and RAW112) lineage cell lines tested but not in a bone marrow-derived stromal cell line $(A C 6)$ or in an interleukin-2 (IL-2)-dependent CTL line (ARl). Thus, LYAR seemed to be expressed at high levels in the transformed leukemia cells tested.

Expression of LYAR in different tissues of adult mice was also examined (Fig. 4B). By Northern blot analyses,
LYAR mRNA was not detected in brain, thymus, liver, bone marrow, heart, or muscle. Low levels of expression were detected in kidney and spleen, and high levels of LYAR mRNA were detected in testis. In situ hybridization with the LYAR cDNA probes confirmed the expression patterns in mouse primary tissues (see below and data not shown). This indicated that the T- and B-cell leukemia lines tested were induced to express the LYAR gene sometime during or after their transformation.

\section{LYAR expression during radiation-induced T-cell leukemogenesis}

As mentioned above, LYAR mRNA was not detectable in thymus or bone marrow but was highly expressed in
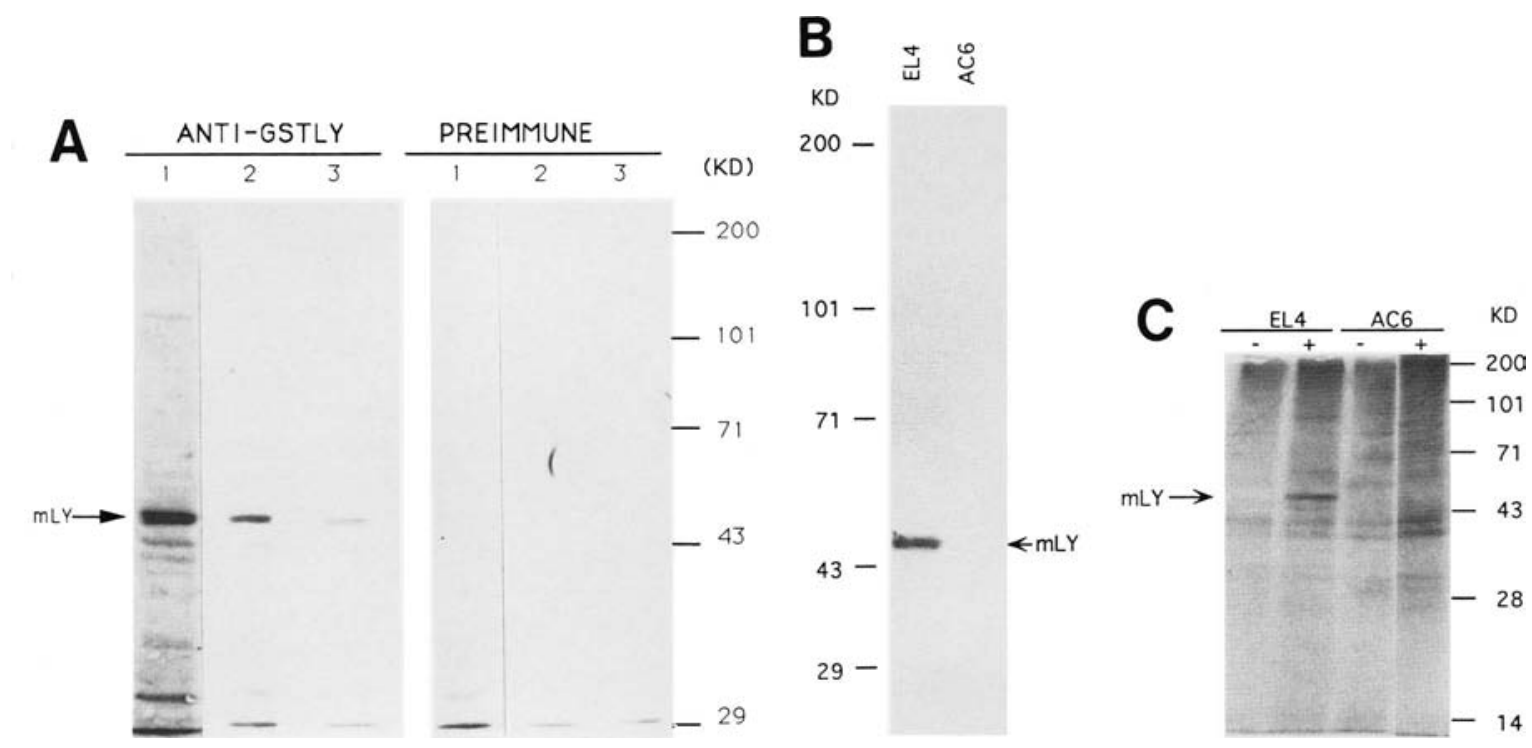

Figure 2. Characterization of the LYAR protein. (A) Western blot analysis of the LYAR protein in EL4 cells with the antisera. Total cell extract from $10^{6}$ cells was loaded in each lane and Western blotted. (Left) Anti-LYAR specific antiserum; (right) preimmune serum. (Lane 1) $1: 1000$ dilution; (lane 2) $1: 2000$ dilution; (lane 3) $1: 5000$ dilution. (mLy) Mouse LYAR protein. (B) Western blot analysis of EL4 and AC6 cells. As in A, anti-LYAR-specific antisenum was used at $1: 2000$ dilution. (Lane 1) Extract from EL4 cells; (lane 2) extract from AC6 cells. (C) Immunoprecipitation of LYAR from EL4 and AC6 cells. Cell extracts labeled with $\left[{ }^{35} \mathrm{~S}\right]$ methionine $\left(5 \times 10^{6}\right.$ $\mathrm{cpm}$ ) from EL4 or AC6 cells were precipitated with preimmune serum (lanes 1) or anti-LYAR serum (lanes 2). (mLY) Mouse LYAR protein. 
A

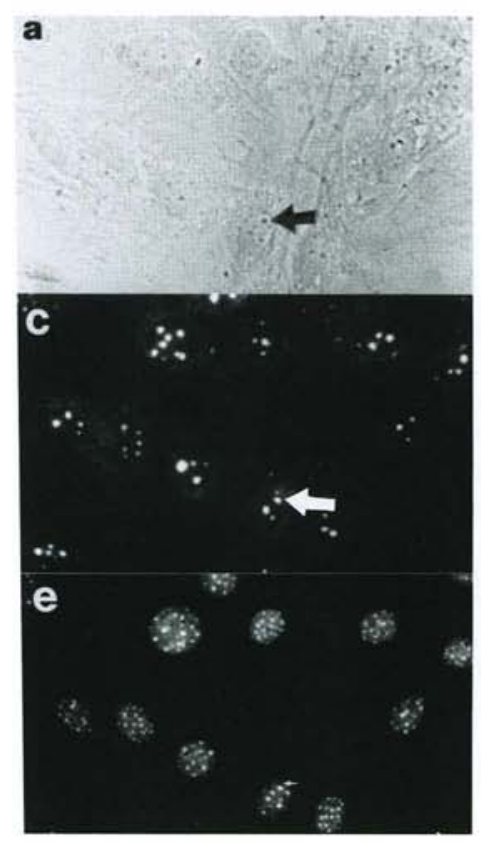

b

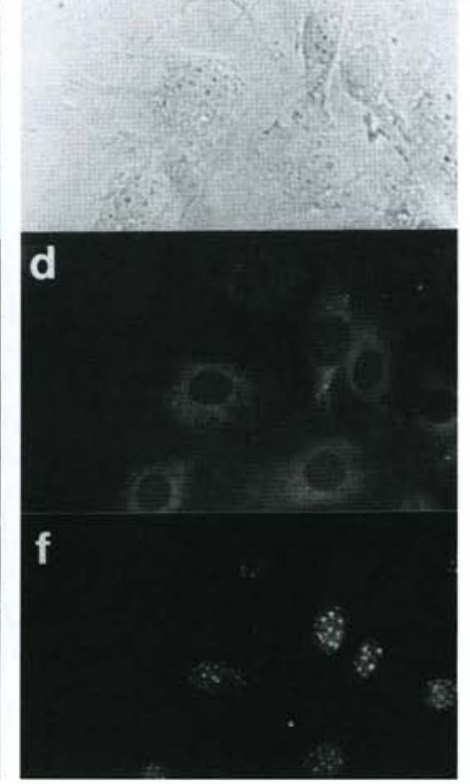

A novel nucleolar oncoprotein

C
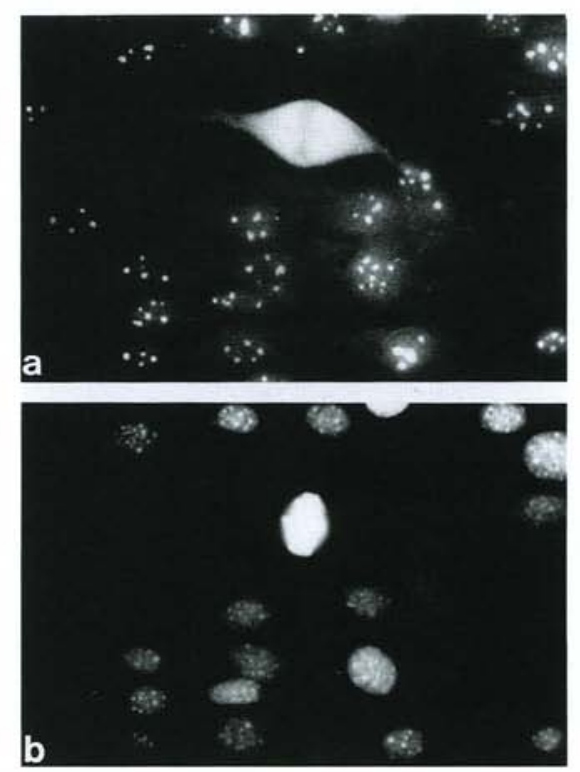

B
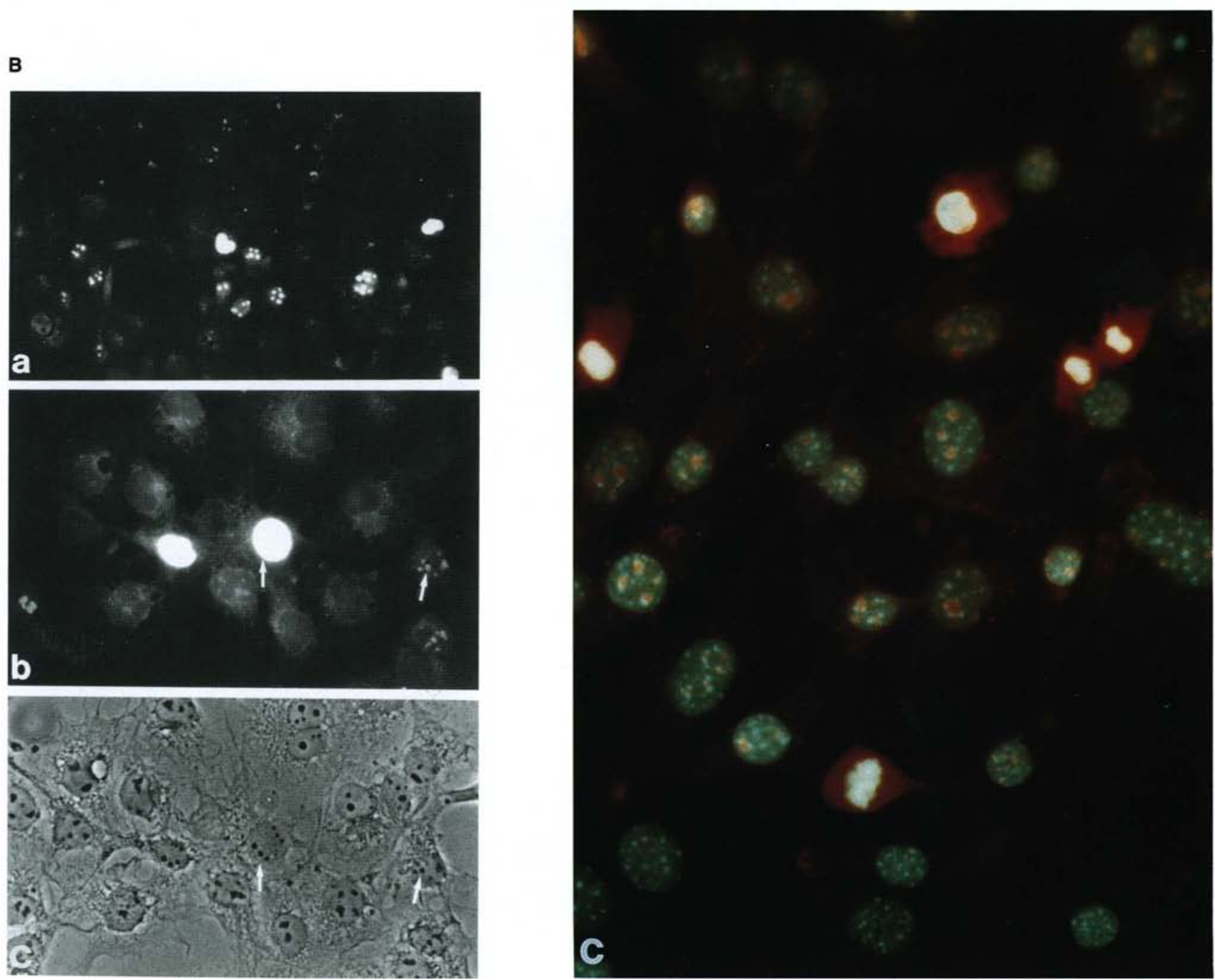

Figure 3. (See following page for legend.) 
all of the $\mathrm{T}$ and $\mathrm{B}$ lineage leukemia cells tested (Fig. $4 A, B \mid$. We therefore decided to test whether the expression of LYAR occurred in the preneoplastic or neoplastic stages of radiation-induced thymic leukemogenesis in mice. C57Bl/Ka mice were exposed to the standard weekly leukemogenic X-ray radiation protocol (Kaplan and Brown 1954|. RNA isolated from thymocytes at different stages following irradiation (12-16 weeks after irradiation for the preleukemic thymocytes or 20-24 weeks after irradiation for the leukemic thymocytes) was blotted and probed with a LYAR-specific probe (Fig. $4 C)$. High levels of LYAR mRNA were detected in thymic populations containing preleukemic thymocytes, as well as in acute leukemic thymocytes.

The increased LYAR mRNA detected could be the result of induction of the LYAR gene in preleukemic or leukemic thymocytes. Alternatively, it could also be attributable to expansion of a minor thymocyte population expressing high levels of LYAR in the normal thymus. To investigate the latter possibility, in situ hybridization was performed with thymus sections from normal mice (Fig. 4D). No cells in the thymus were found to express high levels of the LYAR message. Therefore, expression of the LYAR gene appeared to be highly induced early during the thymic leukemogenesis process.

\section{Expression of the LYAR gene during embryonic development}

The LYAR gene was expressed at high levels in mouse embryonic stem (ES) cells (Fig. 5A, lane 1). Analyses of RNA isolated from day 9 and day 13 embryos also detected high levels of LYAR mRNA (Fig. 5A, lanes 2,3). Low levels of LYAR mRNA were detected in adult spleen, as shown above in Figure $4 \mathrm{~B}$ and in Figure $5 \mathrm{~A}$ (lane 4).

To localize specific tissues expressing LYAR, early embryos were studied for LYAR expression by in situ hybridization. The LYAR mRNA was detected in day 10 fetal liver (Fig. 5B) and day 13 fetal thymus (Fig. 5C). No significant levels of hybridization were detected in fetal heart at either stage. Expression of LYAR was also detected in fetal livers and fetal thymuses of other fetal developmental stages, and in some other tissues such as vertebrae and lung (L. Su and I.L. Weissman, in prep.). Therefore, the LYAR gene is expressed in early embryos and preferentially in some tissues, including fetal liver and fetal thymus, where fetal hematopoiesis is occurring.
The LYAR gene is expressed at very high levels in immature spermatocytes

In adult testis the LYAR mRNA was present at a very high level (Fig. 4B). In situ hybridization was performed to examine what cell types in the testis express the LYAR gene. As shown in Figure 6, LYAR-positive cells appeared to reside at the basal layer of the seminiferous tubules, where the immature spermatocytes are located (Fig. 6A). The Sertoli cells, interstitial cells (Leydig cells), the mature, and maturing spermatozoa did not express detectable levels of LYAR (Fig. 6A, a,b). The sense probe, which served as negative control for specific hybridization, showed no hybridization signal in the testis (Fig. $6 \mathrm{~A}, \mathrm{c}, \mathrm{d})$.

To confirm that the LYAR protein is expressed in immature spermatocytes, immunofluorescence staining of testis sections with the anti-LYAR antibodies was performed (Fig. 6B). The primary and secondary spermatocytes are specifically labeled, consistent with the in situ hybridization results.

To confirm that only the germ cells in testis expressed the LYAR gene, in situ hybridization was performed with testis sections from the germ cell-deficient mouse $\left(\mathrm{W} / \mathrm{W}^{\mathrm{v}}\right)$. It is known that $\mathrm{W} / \mathrm{W}^{\mathrm{v}}$ mice are sterile because they lack germ cells, and the nongerm cells of the testis are all present (Coulumbre and Russell 1954). As expected, no LYAR-positive cells were detected in testis from $\mathrm{W} / \mathrm{W}^{\mathrm{v}}$ mice (Fig. $6 \mathrm{C}$ ).

\section{LYAR is a novel nucleolar protein with oncogenic potential}

We have demonstrated that LYAR is a nucleolar protein with a putative DNA-binding domain. Expression of the LYAR gene seems to correlate with abnormal cell growth. The oncogenic potential of LYAR was tested by overexpressing the LYAR cDNA in a mouse fibroblast cell line (NIH-3T3) via a retrovirus vector. Figure 6 shows that two independent clones stably expressing the LYAR cDNA, Vly12 and Vly36 (Fig. 7A, lanes 1,2), expressed much higher levels of LYAR proteins than the control cells expressing the neomycin resistance gene (Fig. 6A, lane 3) or the parental NIH-3T3 cells (data not shown).

The cells expressing high levels of LYAR /Vly12, Vly22, Vly 36), although not morphologically transformed in vitro (data not shown), showed increased ability (i.e., higher frequency and shorter latent period) to form tumors at the sites of injection than the control

Figure 3. Subcellular localization of LYAR. (A) LYAR is localized in the nucleolus. Mouse EF cells were stained with anti-LYAR antiserum $(a, c, e)$ or preimmune serum $(b, d, f) .(a, b)$ Phase-contrast pictures show the cellular morphology; $(c, d)$ fluorescence signals of anti-LYAR staining; $(e, f)$ DNA (Hoechst dye) staining. The arrows in $a, c$, and $e$ indicate one of the nucleoli stained with the anti-LYAR antibody. $(B)$ The LYAR cDNA encodes the nucleolar protein reactive with the anti-LYAR antibody. COS-7 cells transiently expressing the LYAR cDNA were stained with the anti-LYAR monoclonal antibody. (a) Transfected cells stained with the anti-LYAR monoclonal antibody staining, (magnification, $64 \times) ;(b)$ as in $a$ (magnification, 256 $) ;(c)$ phase contrast of $b$. The arrows show the nucleoli of some LYAR-positive cells. (C) LYAR localization during cell mitosis. Actively dividing mouse EF cells were stained with polyclonal antiserum. (a) Anti-LYAR signals (rhodamine); (b) DNA (Hoechst dye) staining; (c) double exposure of both the anti-LYAR signals (red) and the DNA-staining signals(blue and white). 


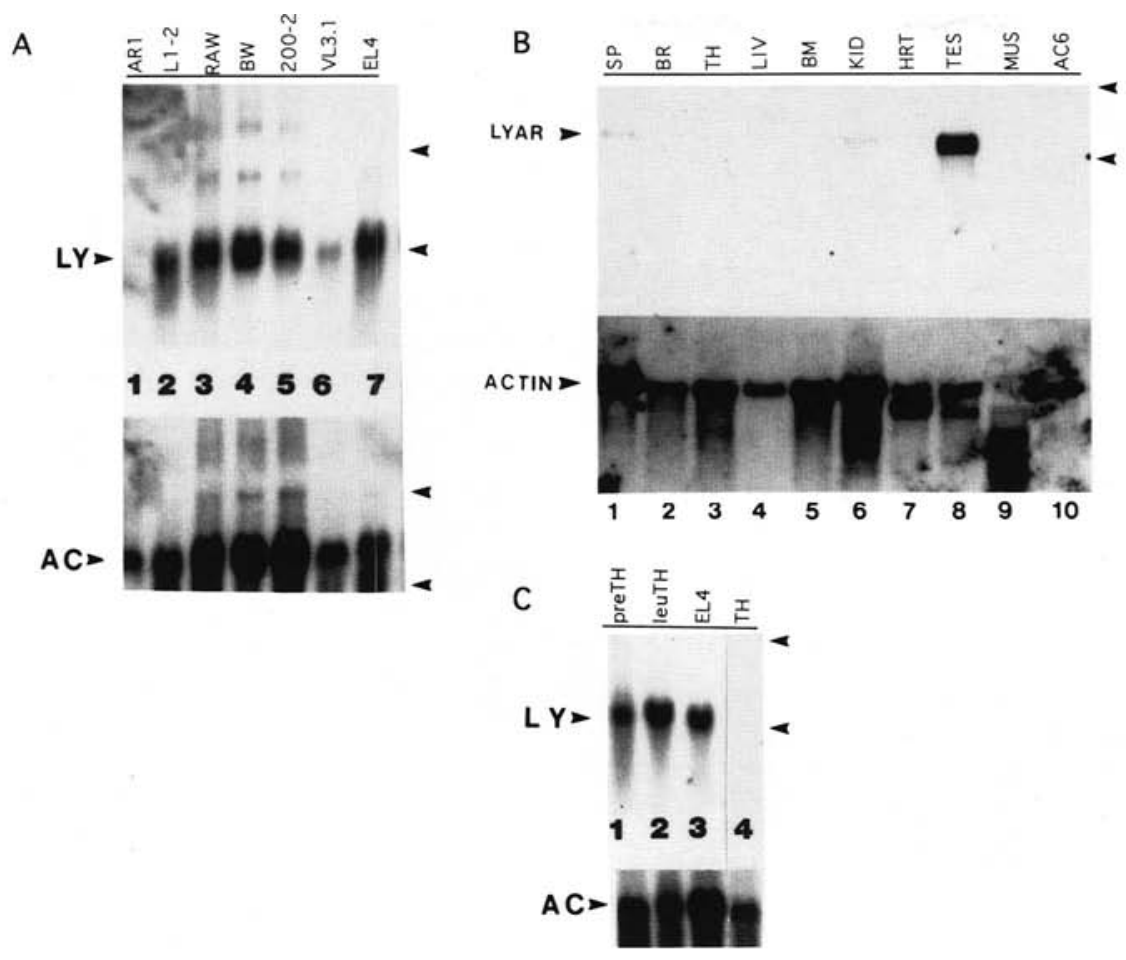

Figure 4. Induction of LYAR mRNA in leukemia cells and during radiation-induced T-cell leukemogenesis. Total cellular RNA (15 $\mu \mathrm{g})$ was loaded on the gel and probed with either the LYAR CDNA or a human $\beta$-actin cDNA. The arrowheads mark the 18S and 28S rRNA bands. $(A)$ LYAR mRNA in different cell lines. AR1 (lane 1), An IL-2-dependent CTL line; L1-2 (lane 2), RAW112 (lane 3) and 200-2 (lane 4), three pre-B cell leukemia lines; BW (lane 5), VL3.1 (lane 6), and EL4 (lane 7), three T-cell leukemia lines. (LY) LYAR mRNA; (AC) actin mRNA. (B) LYAR mRNA in different mouse tissues. (Lane 1) Spleen (SP); (lane 2) brain (BR); (lane 3) thymus (TH); (lane 4) liver (LIV); (lane 5) bone marrow (BM); (lane 6) kidney (KID); (lane 7) heart (HRT); (lane 8) testis (TES); (lane 9) muscle (MUS); (lane 10) bone marrowderived stromal cell line (AC6). (C) LYAR mRNA from mouse thymocytes during radiation-induced thymic leukemogenesis. (Lane 1) Preleukemic thymocytes (preTH); (lane 2) leukemic thymocytes (leuTH); (lane 3) EL4 cells; (lane 4) normal thymocytes (TH). ( $D$ ) Analysis of LYAR mRNA in normal mouse thymus by in situ hybridization. Thymus sections of normal mouse were hybridized with LYAR riboprobes. $(a, b)$ LYAR antisense probe; $(c, d)$ LYAR sense probe; $(a, c)$ phase-contrast pictures showing the tissue section; $(b, d)$ dark-field pictures showing any LYAR mRNA signals (bright white grains).

cells (Neol, Vneo22, Vneo45), when their tumor-forming potential was tested in nu/nu mice (Table 2). Tumors derived from Vly12 were shown to express the LYAR cDNA at high levels (data not shown) and were typical fibrosarcomas (Fig. 7B). The tumor cells could be retransferred to form tumors efficiently in other $\mathrm{nu} / \mathrm{nu}$ mice (Table 2).

The cells expressing the neo gene from the retroviral vector (Vneo22 and Vneo45) or from an expression plasmid (Neol) did not give rise to any visible tumors until the fourteenth week after injection. By that time, some of the mice with tumors from the LYAR cDNA-express- ing cells had died from tumors that were usually $3-4 \mathrm{~cm}$ in diameter. Therefore, overexpression of the LYAR cDNA in NIH-3T3 fibroblast cells rendered them more tumorigenic, indicating that LYAR is a novel nucleolar protein that can be involved in cell growth regulation.

\section{Discussion}

LYAR is a CDNA isolated from a T-cell leukemia line encoding a novel nuclear zinc finger protein

A cDNA was isolated and characterized from a T-cell leukemia, which encoded a polypeptide cross-reactive 

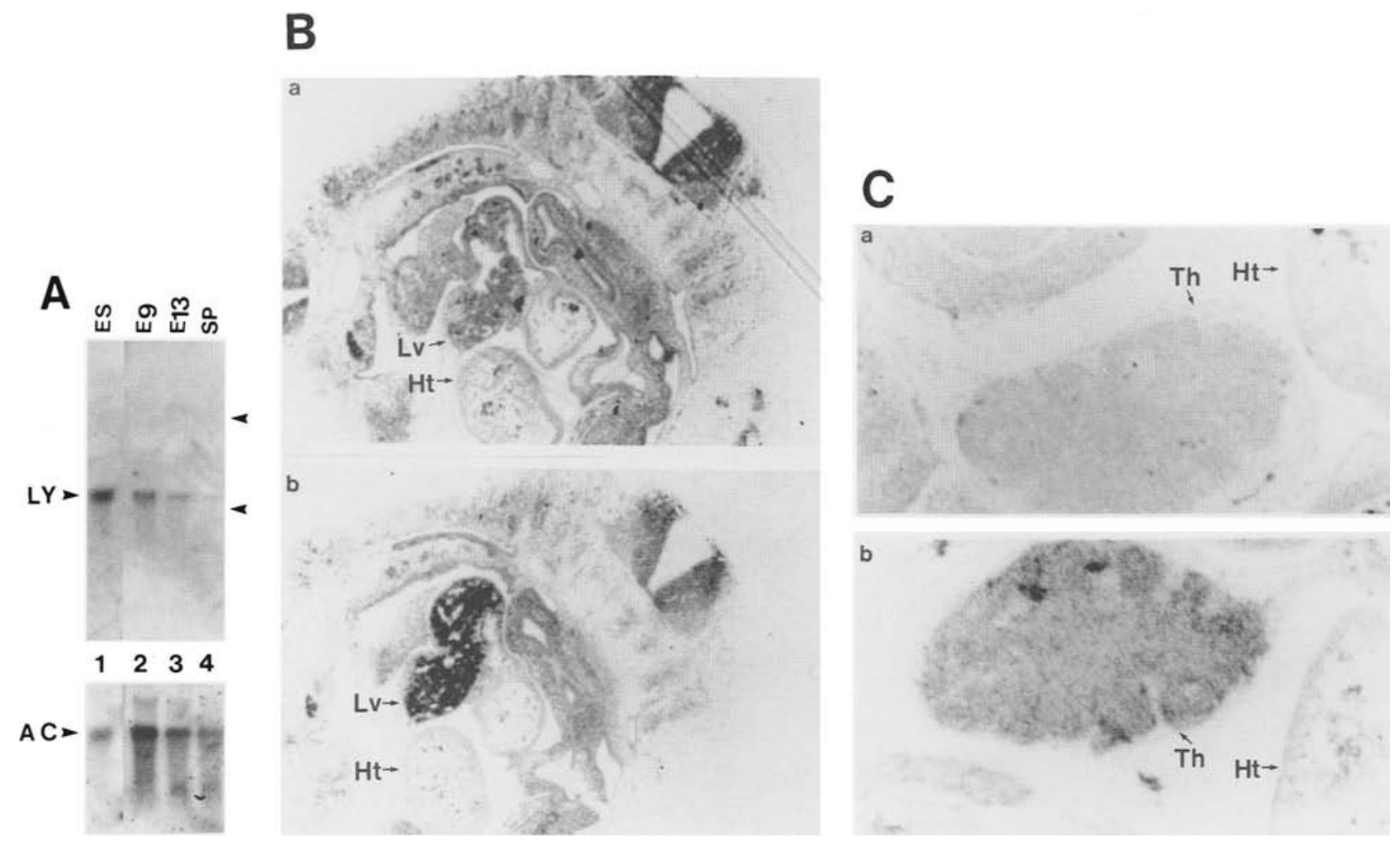

Figure 5. Detection of LYAR mRNA during early fetal development. (A) Northern blot analysis of LYAR mRNA in early embryos, RNA isolated from ES cells (lane 1), day 9 whole embryo (E9, lane 2), day 13 whole embryo (E13, lane 3) or adult spleen (Sp, lane 4) was hybridized with a LYAR-specific probe (LY, top) or a human actin probe (AC, bottom). (B) Detection of LYAR mRNA in day 10 fetal liver by in situ hybridization. The bright-field picture demonstrated that high levels of LYAR RNA were detected (black grains) in fetal liver (Lv) but not in fetal heart $(\mathrm{Ht})$. (a) Day 10 embryo section hybridized with a LYAR sense probe as a background control; (b) day 10 embryo section hybridized with a LYAR antisense probe. Magnification, 19x.(C) Detection of LYAR mRNA in day 13 fetal thymus by in situ hybridization. The bright-field picture showed high levels of LYAR RNA present in day 13 fetal thymus (Th) but not in fetal heart (Ht). $|a|$ Day 13 embryo section hybridized with a LYAR sense probe as a background control; $\{b \mid$ day 13 embryo section hybridized with a LYAR antisense probe. Magnification, $94 \times$.

with the anti-Ly-1 monoclonal antibody 53.7 . The putative gene was mapped by RFLP on mouse chromosome 1 and was not the Ly-1 gene. The LYAR clone encoded a protein that has a unique zinc finger motif within the first 60 amino acid residues and three copies of NLS (Fig. 1).

A new family of zinc finger proteins has been identified recently (Goddard et al. 1991). Like LYAR, these proteins all have eight zinc-binding residues in a cluster at the amino terminus (Fig. 1B). Most of the proteins in this family have been implicated in regulating cell growth or gene expression. For example, PML (de The et al. 1991; Goddard et al. 1991), bim-1 (Goebl 1991; Haupt et al. 1991; van Lohuizen et al. 1991), MEL-18 (Tagawa et al. 1990; Goebl 1991), and rfp (Takahashi et al. 1988) are probably involved in cell transformation; IE110 (Perry et al. 1986), VZV61 (Davison and Scott 1986), and Rpt-1 (Pataraca et al. 1988) are believed to be involved in regulating gene expression; and RAG-1 (Schatz et al. 1989) and RAD-18 (Jones et al. 1988) are involved in site-specific DNA recombination and DNA repair, respectively.

The three copies of putative NLS present in LYAR suggest that its nuclear localization may be of interest (Fig. 1C). The SV40 T antigen signal, which is sufficient to direct most, but not all, proteins into the nucleus, requires other NLS motifs to transport some proteins (Richardson et al. 1986; Greenspan et al. 1988; Morin et al. 19891. Thus, LYAR may use these multiple copies of NLS to direct its nuclear and/or subnuclear localization. Multiple copies of NLS may also play a role in regulated nuclear localization. For example, two copies of NLS have been reported in the glucocorticoid receptor, whose nuclear localization is regulated by binding to steroid hormones (Picard and Yamamoto 1987; Picard et al. 1990).

\section{Nucleolar localization and the putative DNA-binding domain of LYAR}

Immunolocalization of LYAR in different cells clearly showed that LYAR is predominantly localized in the nucleolus (Fig. 3). A putative NLS consisting of mostly positively charged residues has been identified (Siomi et al. 

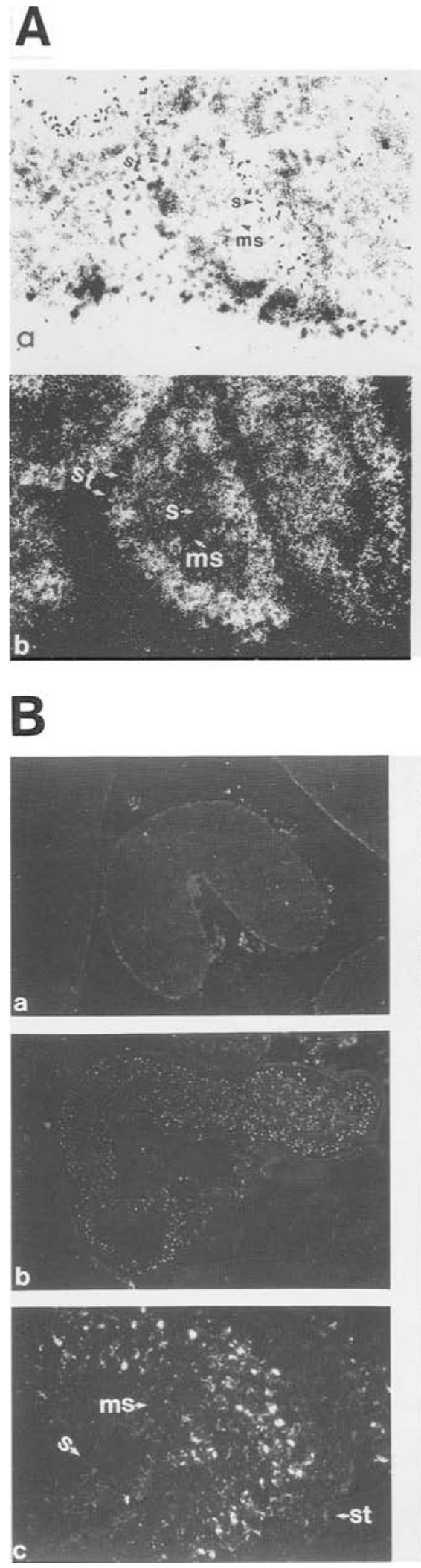
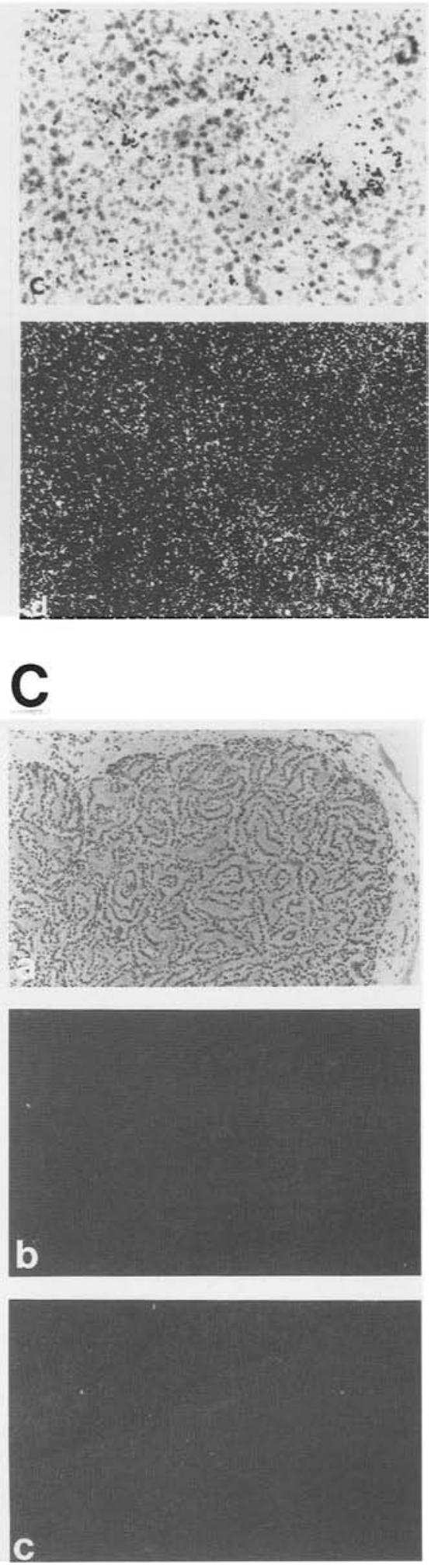

Figure 6. Localization of LYAR-expressing cells in mouse testis. $(A)$ In situ hybridization detection of the LYAR mRNA in mouse testis. $(a, b)$ LYAR antisense probe; $(c, d)$ LYAR sense probe. $a$ and $c$ are brightfield pictures showing the morphology; $b$ and $d$ are dark-field pictures showing the LYAR mRNA hybridization signals (white grains). (st) Sertoli cells; (s) spermatozoa; (ms) maturing spermatozoa. (B) Detection of the LYAR protein in mouse testis by immunofluorescence staining. $(a)$ Testis section was stained with preimmune serum, (magnification, 22 $\times$ ); $|b|$ testis section stained with anti-LYAR specific antiserum, (magnification, $22 \times$ ); (c) anti-LYAR specific antiserum, (magnification, $112 \times$ ). (st) Sertoli cells; (s) spermatozoa; (ms) maturing spermatozoa. (C) Analysis of LYAR mRNA in $W / W^{v}$ mouse testis by in situ hybridization. (a) Phase contrast of the testis section; $(b)$ dark-field picture of testis section hybridized with the LYAR antisense probe; $(c)$ dark-field picture of testis section hybridized with the LYAR sense probe.
1988). The charged region in LYAR (Fig. 1A) has a net positive charge that might serve as a NLS.

The subcellular location of a protein usually impli- cates its potential function in the cell. According to our current understanding of the nucleolus, LYAR may be involved in the following processes: (1) ribosomal gene 


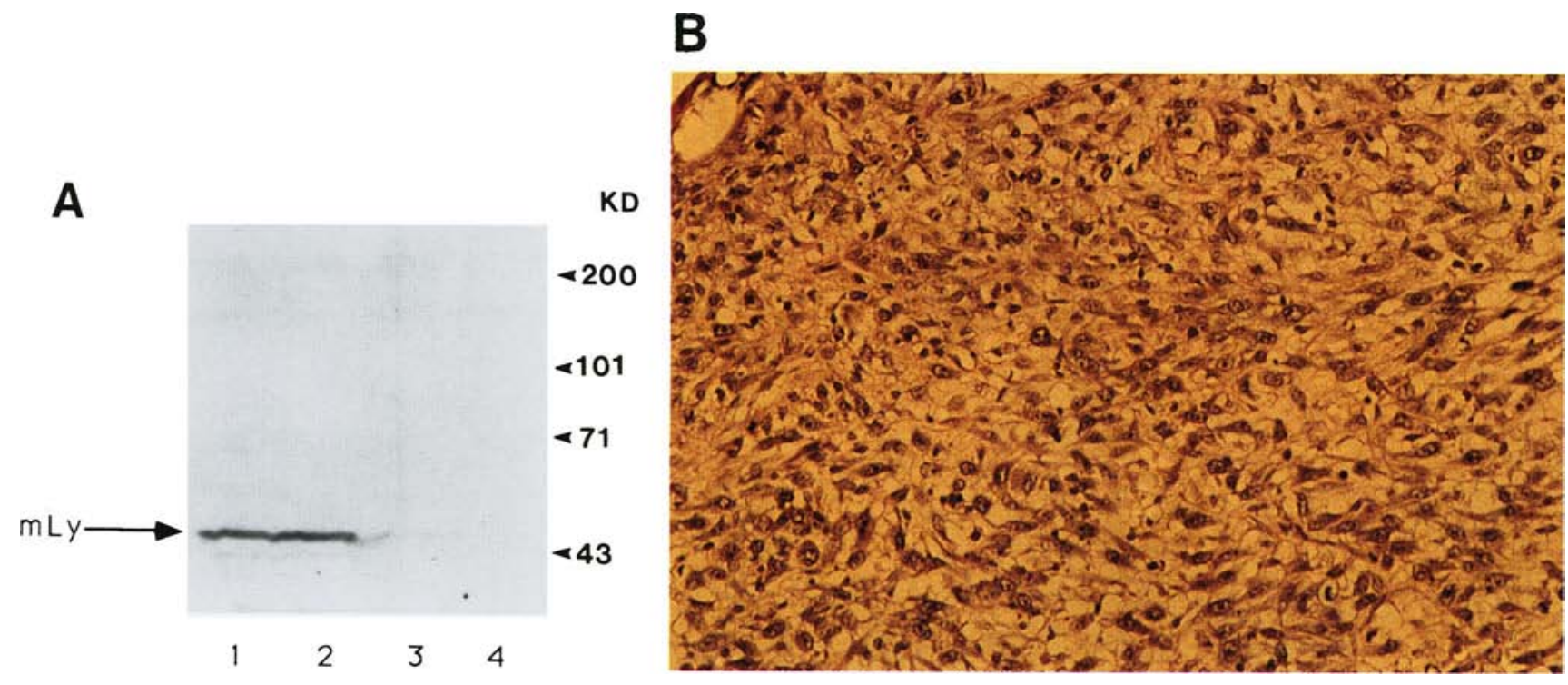

Figure 7. (A) Western blot analysis of NIH-3T3 cells expressing LYAR cDNA. Cell extract from $10^{6}$ NIH-3T3 cells expressing LYAR cDNA Vly12 (lane 1) and Vly36 (lane 2) and cells expressing the neomycin gene Vneo45 (lane 3), and AC6 (bone marrow stromal cell line, lane 4) were analyzed with anti-LYAR serum at $1: 2000$ dilution. (mLy) Mouse LYAR protein. (B) Histology of the fibrosarcoma derived from Vlyl2 in nu/nu mice.

transcription; (2) rRNA processing; (3) ribosome assembly; or (4) protein transport between the nucleus and cytoplasm (Meier and Blobel 1990, 1992).

The zinc finger motifs in LYAR and the fact that the glutathionine $s$-transferase (GST)-LYAR fusion protein can bind to double-stranded DNA with high affinity (L. $\mathrm{Su}$ and I.L. Weissman, unpubl.) strongly suggest that LYAR is a DNA-binding protein. It is conceivable that LYAR may be involved in regulating ribosomal gene transcription. On the other hand, LYAR may also function in other cell compartments either during different stages of development or different stages of the cell cycle. Identification of the DNA sequences interacting with LYAR should be informative about the target genes for LYAR action. Ribosomal genes are candidate targets for LYAR action because of its subcellular location. In addition, general methods can be employed that have been developed to identify the DNA-binding sites of any putative DNA-binding protein (Kinzler and Vogelstein 1989; Mavrothalassitis et al. 1990).

\section{Induction of LYAR during oncogenic transformation}

The LYAR gene is highly expressed in all $\mathrm{T}$ and $\mathrm{B}$ leukemia cells tested but is not detected in normal thymus and bone marrow cells. During the radiation induction of thymic leukemias, the LYAR gene was induced in preleukemic thymocytes and remained active in acute leukemic thymocytes (Fig. 5). Therefore, LYAR expression seemed to be associated with the early stages of oncogenic transformation.

The results described above raised the possibility that LYAR may be associated with cell proliferation in general. However, several lines of evidence indicated that the LYAR gene was not expressed during proliferation of some normal cells. First, actively proliferating cells are present in bone marrow ( $>20 \%$ ), yet no or very low levels of LYAR expression were detected in bone marrow

Table 2. Oncogenicity test of LYAR in NIH-3T3 cells

\begin{tabular}{|c|c|c|}
\hline \multirow[b]{2}{*}{ Cells $^{a}$} & \multicolumn{2}{|c|}{ Tumor } \\
\hline & 8 weeks & 14 weeks \\
\hline \multicolumn{3}{|c|}{ Experiment 1} \\
\hline Neol & $0 / 5$ & $1 / 5^{\mathrm{c}}$ \\
\hline Vly 12 & $4 / 5$ & $5 / 5 \quad(3)^{d}$ \\
\hline Vneo45 & $0 / 5$ & $0 / 5$ \\
\hline \multicolumn{3}{|c|}{ Experiment 2} \\
\hline Vneo22 & $0 / 5$ & $1 / 5$ \\
\hline Vly 12 & $4 / 5$ & $4 / 5 \quad(2)$ \\
\hline Vly22 & $2 / 5$ & $3 / 5 \quad$ (1) \\
\hline Vly36 & $3 / 5$ & $3 / 5 \quad(2)$ \\
\hline Vly $12 \mathrm{~T}^{\mathrm{e}}$ & $10 / 10$ & $10 / 10(8)$ \\
\hline
\end{tabular}

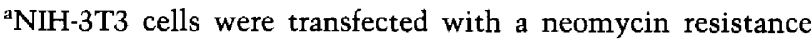
gene (Neo1), with a LYAR cDNA in a retroviral vector (Vly12, Vly22 and Vly36), or with the same retroviral vector expressing the neo gene (Vneo22 and Vneo45), and G418-resistant cells were cloned and analyzed.

${ }^{b}$ About $2 \times 10^{5}$ cells were injected subcutaneously into each $\mathrm{nu} / \mathrm{nu}$ mouse. Tumors at the sites of injection were scored weekly.

${ }^{\text {cSmall tumors } ~}<0.5 \mathrm{~cm}$ in diam.) appeared around the fourteenth week postinjection, when tumors observed at the eighth week were bigger than $3 \mathrm{~cm}$ in diam.

${ }^{\mathrm{d}}$ Number of mice that died from tumors.

'Tumor cells derived from (experiment 1) Vly12-injected nu/nu mice. 
cells (Fig. 5). Second, AR1 (an IL-2-dependent CTL line) can proliferate efficiently in the presence of IL-2, but no LYAR expression was detected in AR1 cells (Fig. 5). Therefore, LYAR expression appeared to be associated with abnormal cell growth.

Interestingly, the LYAR gene was expressed at high levels in ES cells and in a number of fetal tissues including fetal liver and fetal thymus (Fig. 6; L. Su and I.L. Weissman, unpubl.). This suggests that the LYAR function may be important during normal fetal development. The expression of LYAR in immature spermatocyte cells also suggests that LYAR may be involved in growth of undifferentiated cells or early cell differentiation.

\section{LYAR: a novel nucleolar oncoprotein}

We demonstrated that $\mathrm{NIH}-3 \mathrm{~T} 3$ cells overexpressing the LYAR cDNA from a retrovirus vector, when injected into nu/nu mice, had higher activity /higher frequency and shorter latent period) for tumor formation. Therefore, LYAR behaved like an oncoprotein. However, the cells overexpressing LYAR did not grow like completely transformed cells in vitro, that is, no focus formation or anchorage-independent growth in agarose colony assay was detected (data not shown).

Although it has been shown that the nucleoli of tumor cells may be distinguishable from those of normal cells (Busch et al. 1979, 1986) very little is known about the significance of these differences. Proliferating cells and tumor cell-specific nucleolar antigens have been identified. Their precise role in cell proliferation, in transformation, or in the maintenance of tumorigenicity is not clear (Yeoman et al. 1976; Tan 1982; Mathews et al. 1983).

Whereas different types of genetic alterations may all lead to altered expression or function of cell-growth regulatory genes and to abnormal growth, it is generally believed that more than one event is required to lead to the neoplastic transformation of a normal cell to a malignant one (Land et al. 1983; Weinberg 1989). It is conceivable that LYAR may partly transform cells and render them more sensitive to other transformation events that lead to malignant transformation. Alternatively, LYAR may complement a pre-existing transformation event present in the NIH-3T3 fibroblast cell line to cause malignant transformation. Experiments testing the oncogenic potential of LYAR in vivo or in primary cells are in progress.

A new zinc finger-encoding oncogene, $m d m-2$, has been reported recently (Fakharzadeh et al. 1991). The $\mathrm{mdm}-2$ protein has two zinc fingers of $\mathrm{CXXC} / \mathrm{CXXC}$ type. The $m d m-2$ gene is found to be overexpressed in a number of tumor cells. Like LYAR, overexpression of $m d m-2$ in NIH-3T3 cells does not lead to morphologic transformation in vitro, but it can increase tumorigenicity of the cells in nu/nu mice. Two recent studies have reported that $m d m-2$ can physically interact with and modulate the function of the p53 protein to affect cell growth (Momand et al. 1992; Oliner et al. 1992).

\section{Materials and methods}

Cell lines

NIH-3T3 cells, COS-7 cells, and EF cells are maintained in Dulbecco's modified Eagle medium supplemented with $10 \%$ fetal bovine serum (FBS) (Sigma). The T leukemia cells EL4, VL3.1, and BW5147; B leukemia cells L2-1, 200-2, RAW112; and the bone marrow-derived stromal cell line AC- 6 are maintained in RMPI-1640 supplemented with 10\% FBS. The CTL line AR-1 cells are cultured in RMPI-1640 supplemented with $10 \%$ FBS and 5\% RAT T-stim with concanavalin A (Collaborative Research, Inc.).

\section{Molecular cloning and DNA sequence analyses}

A $\lambda$ gt 11 cDNA library of EL4 cells (a gift from T. St. John, ICOS, Seattle, WA) was screened with a monoclonal antibody against the mouse Ly-1 antigen 157.3 .1 ; Ledbetter and Herzenberg 1979), as described previously (St. John et al. 1986). LYAR clones were used to screen the library to get the full-length LYAR cDNA. DNA sequence was obtained by subcloning the cDNA into $\mathrm{M} 13 \mathrm{mp} 18$ and $\mathrm{Ml} 3 \mathrm{mpl}$. Both strands were sequenced by chain termination using the Sequenase 2.0 kit (U.S. Biochemicals).

The DNA sequence was analyzed on the Stanford Cell Biology VAX computer, with the Wisconsin GCG programs, and on the CMGM computer at Stanford, with the IntelliGenetics programs.

\section{Northern blot analyses}

Total RNAs from cell lines or fresh tissues were purified, and 15 $\mu \mathrm{g}$ of total RNA was used for each Northern blot analysis (Ausubel et al. 1989). A human $\beta$-actin cDNA (a kind gift from M. Hu, Stanford University, CA) was used as probe to standardize the amount of RNA from each sample.

\section{In situ hybridization}

In situ hybridization was performed essentially as described (Wilkinson et al. 1987) except that the LYAR cDNA in pBluescript KS or SK (Stratagene) was used as template for T7 RNA polymerase transcription to generate a sense or antisense RNA probe labeled with $\alpha^{-35}$ S-labeled UTP.

\section{LYAR fusion proteins and antibody production}

The entire coding region of LYAR was fused with the bacterial GST gene, and the fusion protein was overexpressed and purified as described (Smith and Johnson 1988). The purified fusion protein was used to immunize rabbits or rats for polyclonal or monoclonal antibody production, respectively. Purified LYAR protein fused with the bacterial maltose binding protein (MBP, New England Biolabs) was used for screening anti-LYAR-positive antibodies by ELISA (Harlow and Lane 1988). The antibodies were purified on protein $A$ or protein $G$ affinity column (Harlow and Lane 1988).

\section{Protein analysis}

Total cell extract from $10^{6}$ cells was analyzed by Western blot as described (Harlow and Lane 1988). The rabbit anti-LYAR serum or preimmune serum was used at different dilutions. Protein A conjugated with horseradish peroxidase (HRP, Sigma) was used as the second-stage reagent, and an ECL Western blot detecting kit (Amersham) was used. 
Immunoprecipitation was performed essentially as described (Harlow and Lane 1988). Briefly, cell extract labeled with $\left[{ }^{35} \mathrm{~S}\right]$ methionine $\left(5 \times 10^{6} \mathrm{cpm}\right)$ was used for each reaction with the antisera, and protein A-Sepharose (Sigma) was used to pellet the rabbit IgG.

For indirect immunofluorescence staining, it was adapted from the protocol described (Harlow and Lane 1988). Cells grown on chamber slides (at $\sim 70 \%$ confluence) were washed with PBS and fixed in $3.7 \%$ formaldehyde for $10 \mathrm{~min}$. The cells were then washed with PBS again and treated with acetone for 2 min. After washing with $\mathrm{H}_{2} \mathrm{O}$ and PBS, the anti-LYAR antibody or control antibody was diluted in PBS and incubated with the cells for $60 \mathrm{~min}$ at room temperature. The cells were then washed three times with PBS and incubated with rhodaminelabeled goat anti-rabbit IgG antibody for $60 \mathrm{~min}$. After the second antibody staining, the cells were incubated with Hoechst dye 33342 (CalBiochem) at $400 \mathrm{nM}$ for $15 \mathrm{~min}$ at room temperature, followed by three washes with PBS. A Nikon (Nikon, Inc.) microscope was used for imaging and photography.

\section{Radiation induction of T-cell leukemia in C57Bl/Ka mice}

The radiation protocol was as described (Kaplan and Brown 1954). Cells from preleukemic thymuses were isolated from mice 12-16 weeks after the initial irradiation. Thymocytes at this stage contain a subpopulation that has acquired leukemogenic potential but is not fully transformed. Leukemic thymocytes were isolated from mice 20 weeks after the initial irradiation, when the mice had visible lymphoma in the thymus.

\section{Transient expression of LYAR cDNA in COS-7 cells}

LYAR cDNA was cloned into pSDD2 vector (a gift from D. Denny, Stanford University, CA) and transfected into COS-7 cells by the DEAE-dextran method as described (Ausubel et al. 19891 .

\section{Stable transfection of LYAR CDNA in NIH-3T3 cells}

LYAR cDNA cloned in a retrovirus vector /a gift from $C$. Shih, Systemix, Palo Alto, CA) was cotransfected with pGKneo (a gift from $\mathrm{E}$. Li, MIT, Cambridge, MA) into NIH-3T3 cells, and G418resistant cells were cloned. Cells transfected with pGKneo alone or with the same retrovirus vector expressing the neomycin resistance gene were also selected and cloned.

\section{Tumorigenicity test in $\mathrm{nu} / \mathrm{nu}$ mice}

Stable transfectants were expanded, and $2 \times 10^{5}$ cells were injected subcutaneously into each nu/nu mouse. Tumors at the injection sites were monitored weekly for at least 14 weeks.

\section{Mapping the chromosomal location of the LYAR gene} with recombinant inbred mice

A RFLP was identified for the LYAR probe between the inbred mouse strains $\mathrm{C} 57 \mathrm{Bl} / 6$ and DBA using the restriction enzymes $K p n I$ and ApaI. Segregation of this RFLP marker was examined in $21 \mathrm{BXD}$ recombinant inbred strains, kindly provided by Benjamin Taylor (Jackson Laboratory; Bar Harbour, ME). The resultant pattern was compared with 144 other markers on 16 chromosomes from the BXD strains (Taylor 1989). Linkage was determined by $\mathrm{X}^{2}$ analysis.

\section{Acknowledgments}

We thank L. Jerabek, L. Hu, and V. Braunstein for their technical help. We are grateful to G. Barsh, M. Clearly, D. Crowe, H. Fleming, R. Nusse, M. Trahey, and D. Vaux for their helpful criticisms and discussions. We also thank J. Friedman, R. Chen, and other members of the laboratory for sharing reagents; $R$. Mebius for helping with immunohistochemistry; B. Taylor for the recombinant inbred mice; and $\mathrm{H}$. Roeland for his advise on in situ hybridization. This work was supported in part by grant CA42551 (I.L.W.) and the Howard Hughes Medical Institute. L.S. was a postdoctoral fellow of the Irvington Institute for Medical Research.

The publication costs of this article were defrayed in part by payment of page charges. This article must therefore be hereby marked "advertisement" in accordance with 18 USC section 1734 solely to indicate this fact.

\section{References}

Ausubel, F.M., R. Brent, R.E. Kingston, D.D. Moore, J.G. Seidman, J.A. Smith, and K. Struhl. 1989. Current protocols in molecular biology. Wiley Interscience, New York.

Bailey, D.W. 1971. Recombinant inbred strains: an aid to finding identity, linkage, and function of histocompatibility and other genes. Transplantation 11: 325-327.

Berg, J. 1986. Potential metal-binding domains in nucleic acid binding proteins. Science 232: 485-487.

Busch, H., F. Gyorkey, R.K. Busch, F.M. Davis, P. Gyorkey, and K. Smetana. 1979. A nucleolar antigen found in a broad range of human malignant tumor specimens. Cancer Res. 39: 3024-3030.

Busch, H., R.K. Busch, P.K. Chan, A. Chatterjee, J. Freeman, B. Ross, A. Black, M. Yaneva, and E. Durban. 1986. Nucleolar antigens in cancer tissues. /. Tumor Marker Oncol. 1: 69-80.

Chan, E., J. Hamel, J. Buyon, and E. Tan. 1991. Molecular definition and sequence motifs of the $55-\mathrm{kD}$ component of human SS-A/Ro autoantigen. J. Clin. Invest. 87: 68-77.

Coulumbre, J.L. and E.S. Russell. 1954. Analysis of the pleiotropism at the w-locus in the mouse. J. Exp. Zool. 126: 277291.

Davidson, M.T., T.H. Roderick, and D.P. Doolittle. 1989. Recombination percentages and chromosomal assignments. In Genetic variants and strains of the laboratory mouse led. M.F. Lyon and A.G. Searle), pp.432-505. Oxford University Press, Oxford, England.

Davison, A.J. and J.E. Scott. 1986. The complete DNA sequence of varicella zoster virus. J. Gen. Virol. 67: 1759-1816.

de The, H., C. Lavau, A. Marchio, C. Chomienne, L. Degos, and A. Dejean. 1991. The PML-RARa fusion mRNA generated by the $t(15 ; 17)$ translocation in acute promyelocytic leukemia encodes a functionally altered RAR. Cell 66: 675-684.

Dynan, W.S. and R. Tiian. 1983. The promoter-specific transcription factor $\mathrm{Spl}$ binds to upstream sequences in the SV40 early promoter. Cell 35: 79-89.

Fakharzadeh, S.S., S.P. Trusko, and D.L. George. 1991. Tumorigenic potential associated with enhanced expression of a gene that is amplified in a mouse tumor cell line. EMBO $/$. 10: $1565-1569$.

Goddard, A.D., J. Borrow, P.S. Freemont, and E. Solomon. 1991. Characterization of a zinc finger gene disrupted by the t $\{15 ; 17\}$ in acute promyelocytic leukemia. Science 254: $1371-1374$.

Goebl, M.G. 1991. The bim-1 and mel-18 gene products define a new family of DNA-binding proteins involved in cell proliferation and tumorigenesis. Cell 66: 623. 
Greenspan, D., P. Palese, and M. Krystal. 1988. Two nuclear location signals in the influenza virus NS1 non-structural protein. I. Virol. 62: 3020-3026.

Harlow, E. and D. Lane. 1988. Antibodies: A laboratory manual. Cold Spring Harbor Laboratory, Cold Spring Harbor, New York.

Haupt, Y., W.S. Alexander, G. Barri, S.P. Kliinken, and J.M Adams. 1991. Novel zinc finger gene implicated as myc collaborator by retrovirally accelerated lymphomagenesis in Eu-myc transgenic mice. Cell 65: 753-763.

Hershberger, R.J. 1989. "A serine protease made by the cytotoxic lymphocytes." Ph.D. thesis, Stanford University, Stanford, CA.

Huang, H.S., N.H. Jones, J.L. Strominger, and L.A. Herzenberg. 1987. Molecular cloning of Ly-1, a membrane glycoprotein of mouse $\mathrm{T}$ lymphocytes and a subset of $\mathrm{B}$ cells: Molecular homology to its human counterpart Leu-1/T1(CD5). Proc. Natl. Acad. Sci. 84: 204-208.

Iones, J.S., S. Weber, and L. Prakash. 1988. The Saccharomyces cerevisiae RAD-18 gene encodes a protein that contains potential zinc finger domains for nucleic acid binding and a putative nucleotide binding sequence. Nucleic Acid Res. 16: $7119-7131$

Kalderon, D, W.D. Richardson, A.T. Markham, and A.E. Smith. 1984a. Sequence requirements for nuclear location of simian virus 40 large $\mathrm{T}$ antigen. Nature 311: 33-38.

Kalderon, D., B.L. Roberts, W.D. Richardson, and A.E. Smith. $1984 \mathrm{~b}$. A short amino acid sequence able to specify nuclear location. Cell 39: 499-509.

Kaplan, H.S. and M.B. Brown. 1954. Development of lymphoid tumors in non-irradiated thymic grafts in thymectomized irradiated mice. Science 119: 439-440.

Kinzler, K.W. and B. Vogelstein. 1989. Whole genome PCR: Application to the identification of sequences bound by gene regulatory proteins. Nucleic Acid Res. 17: 3645-3653.

Krappa, R. and D. Knebel-Morsdorf. 1991. Identification of the very early transcribed baculovirus gene PE-38. I. Virol. 65: $805-812$.

Land, H., L.F. Parada, and R.A. Weinberg. 1983. Tumorigenic conversion of primary embryo fibroblasts requires at least two cooperating oncogenes. Nature 304: 596-602.

Ledbetter, J.A. and L.A. Herzenberg. 1979. A monoclonal antibody specifically recognizes the Ly-1 antigen on murine $\mathrm{T}$ cells. Immunol. Rev. 47: 63-90.

Mathews, M.B., R.M. Bernstein, B.R. Frank, and J.L. Garrels. 1983. Identification of the proliferating cell nuclear antigen and cyclin. Nature 309: 374-376.

Mavrothalassitis, G., G. Beal, and T.S. Papas. 1990. Defining target sequences of DNA-binding proteins by random selection and PCR: determination of the GCN4 binding sequence reportoire. DNA Cell Biol. 9: 783-788.

Meier, U.T. and G. Blobel. 1990. A nuclear localization signal binding protein in the nucleolus. $J$. Cell Biol. 111:22352245.

-2. 1992. Noppl40 shuttles on tracks between nucleolus and cytoplasm. Cell 70: 127-138.

Mellentin, J.D., S.D. Smith, and M.L. Cleary. 1989. lyl-1, a novel gene altered by chromosomal translocation in $\mathrm{T}$ cell leukemia, codes for a protein with a helix-loop-helix DNA binding motif. Cell 58: 77-83.

Miller, J., A.D. McLachlan, and A. Klug. 1985. Repetitive zincbinding domains in the protein transcription factor IIIA from Xenopus oocytes. EMBO J. 4: 1609-1614

Momand, J., G.P. Zambetti, D.C. Olson, D. George, and A.J. Levine. 1992. The mdm-2 oncogene product forms a complex with the p53 protein and inhibits p53-mediated trans- activation. Cell 69: 1237-1245.

Morin, N., C. Delsert, and D.F. Klessig. 1989. Nuclear localization of the adenovirus DNA binding protein: Requirement for two signals and complementation during viral infection. Mol. Cell. Biol. 9: 4372-4380.

Oliner, J.D., K.W. Kinzler, P.S. Meltzer, D.L. George, and B. Vogelstein. 1992. Amplification of a gene encoding a p53associated protein in human sarcomas. Nature 358: 80-83.

Pataraca, R., J. Schwartz, R.P. Singh, Q.T. Kong, E. Murphy, Y. Anderson, F.Y.W. Sheng, P. Singh, K.A. Johnson, S.M. Guarnagia, T. Durfee, F. Blattner, and H. Cantor. 1988. rpt-1, an intracellular protein from helper/inducer $\mathrm{T}$ cells that regulates gene expression of interleukin 2 receptor and human immunodeficiency virus type 1. Proc. Nat1. Acad. Sci. 85: 2733-2737.

Perry, L.J., F.J. Rixon, R.D. Everett, M.C. Frame, and D.J. McGeoch. 1986. Characterization of the IE110 gene of herpes simplex virus type 1. J. Gen. Virol. 67: 2365-2380.

Picard, D. and K. Yamamoto. 1987. Two signals mediate hormone dependent nuclear localization of the glucocorticoid receptor. EMBO I. 6: 3333-3340.

Picard, D., V. Kumar, P. Chambon, and K. Yamamoto. 1990. Signal transduction by steroid hormones: Nuclear localization is differentially regulated in estrogen and glucocorticoid receptor. Cell Regul. 1: 291-299.

Reddy, A.B., A. Chatterjee, L.I. Rothblum, A. Black, and H. Busch. 1989. Isolation and characterization of complementary DNA to proliferating cell nucleolar antigen P40. Cancer Res. 49: 1763-1767.

Richardson, W.D., B.L. Roberts, and A.E. Smith. 1986. Nuclear location signals in polyoma virus large T. Cell 44: 77-85.

Robbins, J., S.M. Dilworth, R.A. Laskey, and C. Dingwall. 1991. Two interdependent basic domains in nucleoplasmin nuclear targeting sequence: Identification of a class of bipartite nuclear targeting sequence. Cell 64: 615-623.

St. John, T., W.M. Gallatiin, M. Siegelman, H.T. Smith, V.A. Fried, and I.L. Weissman. 1986. Expression cloning of a lymphocyte homing receptor cDNA: Ubiquitin is the reactive species. Science 231: 845-850.

Schatz, D.G., M.A. Oettinger, and D. Baltimore. 1989. The V(D|J recombination activating gene, RAG-1. Cell 59: 1035-1048.

Siomi, H., H. Shida, S.H. Nam, T. Nosaka, M. Maki, and M. Hatanaka. 1988. Sequence requirements for nucleolar localization of human $\mathrm{T}$ cell leukemia virus type I $\mathrm{pX}$ protein, which regulates viral RNA processing. Cell 55: 197-209.

Smiley, B.L., A.W. Stadnyk, P.J. Myler, and K. Stuart. 1990. The trypanosome leucine repeat gene in the variant surface glycoprotein expression site encodes a putative metal-binding domain and a region resembling protein-binding domains of yeast, Drosophila, and mammalian proteins. Mol. Cell, Biol. 10: 6436-6444.

Smith, D.B. and K.S. Johnson. 1988. Single-step purification of polypeptides expressed in Escherichia coli as fusions with glutathione S-transferase. Gene 67: 31-40.

Tagawa, M., T. Sakamoto, K. Shigemoto, H. Matsubara, Y. Tamura, T. Ito, I. Nakamura, A. Okitsu, K. Imai, and M. Taniguchi. 1990. Expression of novel DNA-binding protein with zinc finger structure in various tumor cells. $J$. Biol. Chem. 265: 20021-20026.

Takahashi, M., Y. Inaguma, H. Hiai, and F. Hirose. 1988. Developmentally regulated expression of a human "finger"containing gene encoded by the 5 ' half of the ret transforming gene. Mol. Cell. Biol. 8: 1853-1856.

Tan, E.M. 1982. Autoantobodies to nucleolar antigens (ANA), their immunobiology and medicine. Adv. Immunol. 33: $167-240$. 
Su et al.

Taylor, B.A. 1989. Recombinant inbred strains. In Genetic variants and strains of the laboratory mouse (ed. M.F. Lyon and A.G. Searle |, pp. 769-793. Oxford University Press, Oxford, England.

Thiem, S.M. and L.K. Miller. 1989. A baculovinus gene with a novel transcription pattern encodes a polypeptide with a zinc finger and a leucine zipper. I. Virol. 63: 4489-4497.

van Lohuizen, M., S. Verbeek, B. Scheijen, E. Wientjens, H. van der Gulden, and A. Berns. 1991. Identification of cooperating oncogenes in Eu-myc transgenic mice by provirus tagging. Cell 65: 737-752.

Weinberg, R.A. 1989. Oncogenes, anti-oncogenes and molecular basis of multistep carcinogenesis. Cancer Res. 49: 37133721 .

Wilkinson, D.G., J.A. Bailes, J.E. Champion, and A.P. McMahon. 1987. A molecular analysis of mouse development from 8 to 10 days post coitum detects changes only in embryonic globin expression. Development 99: 493-500.

Yeoman, L.C., J.J. Jordon, R.K. Busch, C.W. Taylor, H. Savage, and $\mathrm{H}$. Busch. 1976. A fetal protein in the chromatin of Novikoff hepatoma and Walker 256 carcinosarcoma tumors that is absent from normal and regenerating rat liver. Proc. Natl. Acad. Sci. 73: 3258-3262. 


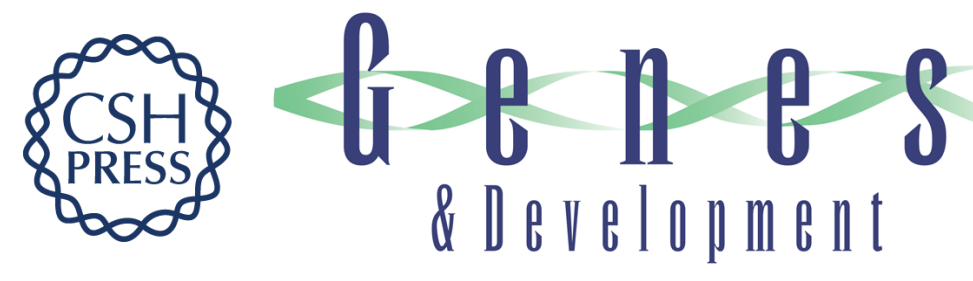

\section{LYAR, a novel nucleolar protein with zinc finger DNA-binding motifs, is involved in cell growth regulation.}

L Su, R J Hershberger and I L Weissman

Genes Dev. 1993, 7:

Access the most recent version at doi:10.1101/gad.7.5.735

References This article cites 52 articles, 19 of which can be accessed free at:

http://genesdev.cshlp.org/content/7/5/735.full.html\#ref-list-1

License

Email Alerting

Receive free email alerts when new articles cite this article - sign up in the box at the

Service top right corner of the article or click here.

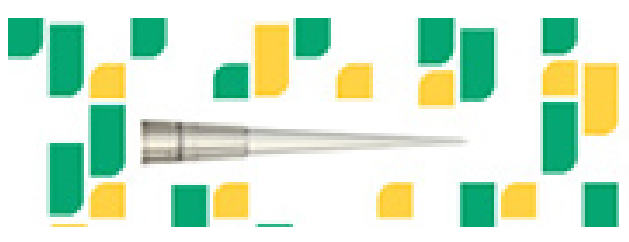

Focused on your science. 